\title{
EMPRÉSTIMOS BANCÁRIOS CONSIGNADOS DE DUAS OU MAIS INSTITUIÇÓES FINANCEIRAS: UMA PERSPECTIVA À LUZ DO DIREITO DO CONSUMIDOR COMO DIREITO FUNDAMENTAL
}

\author{
BANK PAYROLL LOANS CONTRACTED FROM TWO OR MORE FINANCIAL INSTITUTIONS: \\ A PERSPECTIVE IN LIGHT OF CONSUMER LAW AS A FUNDAMENTAL RIGHT
}

\author{
Miguel Ângelo Portela Pinheiro \\ Bacharel em Direito pela Universidade \\ Federal do Rio de Janeiro (UFRJ) \\ Tutor na Universidade Federal \\ do Estado do Rio de Janeiro (UNIRIO) \\ Advogado \\ miguel.pinheiro@adv.oabrj.org.br
}

\begin{abstract}
RESUMO
O presente artigo visa trazer luz ao fato de que a concessão de empréstimos consignados em contracheque por parte de bancos e fornecedoras de crédito sem uma verificação apurada da saúde financeira do consumidor constitui prática abusiva. Este tipo de crédito deve tomar até $30 \%$ do salário líquido e é dividido em parcelas que são descontadas diretamente no contracheque do cliente, o que pode comprometer a sua subsistência e de sua família, especialmente no contexto de superendividamento em que se encontram boa parte dos brasileiros. Esta realidade é inaceitável no âmbito da Constituição Cidadã de 1988, cujo valor central é o princípio da dignidade da pessoa humana, e do Código de Defesa do Consumidor, que foi o subsistema concebido a partir da positivação da defesa do consumidor como direito fundamental no art. $5^{\circ}$, XXXII. Esta previsão expressa devese à ligação íntima entre a dignidade da pessoa humana e a dignidade do consumidor, pois o consumo é parte indissociável da vida nos tempos atuais e se dá em uma relação naturalmente desequilibrada entre fornecedores e consumidores. Deste modo, instituiçóes financeiras devem verificar pormenorizadamente as condiçóes de seus clientes assumirem empréstimos consignados, sob pena de sofrerem revisão contratual na esfera judicial a fim de acomodarem os empréstimos em mais parcelas quanto forem necessárias que não ultrapassem os 30\% estabelecidos pela Lei Federal no 10.820/2003. A defesa da dignidade enquanto direito fundamental da personalidade em muito supera o direito à satisfação do crédito por parte de bancos e organizaçóes afins.
\end{abstract}

Palavras-chave: Empréstimo consignado. Direito do Consumidor. Direito Fundamental. Superendividamento. 


\begin{abstract}
This article aims to shed light on the fact that paycheck-deductible loans by banks and credit providers without an accurate verification of the consumer's financial health is an abusive practice. This type of credit must take up to 30\% of the net salary and is divided into installments that are deducted directly from the customer's paycheck, which may compromise his or her family's subsistence, especially in the context of over-indebtedness in which a large part of Brazilians live. This reality is unacceptable under the Constitution of 1988, whose central value is the principle of human dignity, and the Consumer Protection Code, which was the subsystem conceived from the appointing of consumer protection as a fundamental right in art. 5th, XXXII. This is due to the intimate connection between human dignity and consumer dignity, since consumption is an inseparable part of life today and occurs in a naturally unbalanced relationship between suppliers and consumers. Accordingly, financial institutions must verify in detail the conditions of their customers to take payroll loans, otherwise they will be subject to contractual review in the judicial sphere in order to accommodate the loans in more installments as necessary, not exceeding the $30 \%$ established by Federal Law No. 10.820/2003. The defense of dignity as a fundamental right of personality far outweighs the right to credit satisfaction by banks and related organizations.
\end{abstract}

Key-words: Payroll loan. Consumer law. Fundamental right. Over indebtedness.

Data de submissão: 20/11/2019

Data de aceitação: 01/04/2020

\title{
SUMÁRIO
}

INTRODUCÃO 1. CONTRATOS DE EMPRÉSTIMO CONSIGNADO 2. DIREITO DO CONSÜMIDOR COMO DIREITO FUNDAMENTAL 3. MANUTENÇÃO DA MARGEM CONSIGNÁVEL DE 30\% COMO MATERIALIZAÇÃO DA DIGNIDADE DO CONSUMIDOR. CONSIDERAÇÓES FINAIS.

\section{INTRODUÇÁO}

As relações entre consumidores e fornecedores têm se revelado particularmente complexas e desiguais. A hipossuficiência inerente à condiçăo de consumidor tem se acentuado a partir de condutas predatórias empreendidas especialmente por grandes empresas. O cenário previamente ilustrado amolda-se às relaçôes estabelecidas entre clientes e bancos ou instituições financeiras que fornecem empréstimos consignados em folhas de 
pagamento. Estes contratos de mútuo têm sido muito utilizados, porém a conjuntura precisa ser examinada pelo viés das condiçóes financeiras do contratante para honrar esse compromisso sem prejudicar a sua dignidade enquanto cidadáo e consumidor. $\mathrm{O}$ superendividamento, fruto da crise econômica que prejudica sobretudo os brasileiros mais pobres, é uma realidade que precisa ser combatida em todos os âmbitos.

Bancos e fornecedoras de crédito não deveriam conceder os referenciados empréstimos sem uma análise pormenorizada da saúde financeira do consumidor. Além disso, devem se certificar de que já não existe um empréstimo consignado previamente assinado com outra instituição. O limite máximo de descontos que podem ser efetuados a título de empréstimos consignados é de $30 \%$ do salário líquido do trabalhador, ex vi do art. $1^{\circ}$, $\$ 1^{\circ}$ da Lei Federal no $10.820 / 2003$. Quando esta margem consignável é ultrapassada, é amplamente reconhecida na doutrina e na jurisprudência a imposição de revisão contratual, a fim de acomodar o valor emprestado dentro de parcelas que náo superem o percentual legalmente estipulado.

No entanto, o quadro torna-se mais complexo ao envolver mais de uma concedente de empréstimo, especificamente quando estas não ultrapassam o percentual de $30 \%$ isoladamente, mas somadas comprometem grande parte dos vencimentos do cliente. A acomodação de todos os mutuantes dentro da margem consignável de $30 \%$ é uma mera consequência da posição topográfica da defesa do consumidor no sistema jurídico pátrio, visto que é positivada como direito fundamental (CRFB, art. 5०, XXXII), condição advinda da sua íntima relação com o princípio fundamental da dignidade da pessoa humana (CRFB, art. 10, III).

Neste sentido, a pesquisa de metodologia teórico-bibliográfica que originou este artigo exsurge da atuação advocatícia do autor, após ter obtido sucesso em primeira instância em ação paradigma com a causa de pedir aqui explicitada. Posteriormente, ocorreram outros contatos de potenciais clientes solicitando a redução do percentual de descontos de empréstimos consignados contraídos em mais de uma instituição financeira ou bancária. A recorrência indicou a iteração de prática condenável adotada por bancos e corporaçóes afins, qual seja a não verificação das condiçôes do cliente de arcar com os empréstimos contratados, especialmente tratando-se de consignação em contracheque, comprometendo percentual superior aos $30 \%$ permitidos.

É o que será exposto ao longo deste trabalho, tendo como prisma de análise a concepçâo da defesa do consumidor como direito fundamental.

\section{CONTRATOS DE EMPRÉSTIMO CONSIGNADO}

Os empréstimos consignados constituem uma espécie de linha de crédito bastante popular, pois possuem juros mais baixos por oferecerem menos riscos para as instituiçóes bancárias. Isso ocorre porque os descontos das parcelas ocorrem diretamente nas folhas de pagamento dos contratantes, diminuindo o risco de inadimplência. Por conseguinte, é 
um empréstimo mais facilmente obtido do que o crédito pessoal. ${ }^{1}$

A natureza jurídica deste tipo de linha de crédito é de contrato mútuo, previsto no art. 586 do Código Civil/2002, e oneroso, devido à estipulação de juros, sendo denominado "mútuo feneratício" por Carlos Roberto Gonçalves. ${ }^{2}$ A composição do referido negócio jurídico deve observar os princípios basilares do direito contratual como a boa-fé objetiva e a funçáo social do contrato. Este dever pressupóe que a parte com maior poder deve se abster de práticas impróprias direcionadas ao consumidor, presumidamente hipossuficiente.

No intuito de conter eventuais arbitrariedades, a Lei Federal no 10.820/2003, no seu art. $1^{\circ}, \mathbb{S} 1^{\mathrm{o}}$ e incisos, determina um limite para os descontos advindos de empréstimos consignados em contracheque para empregados celetistas, in verbis:

Art. 1ำ Os empregados regidos pela Consolidaçấo das Leis do Trabalho - CLT, aprovada pelo Decreto-Lei $\mathrm{n}^{\circ} 5.452$, de $1^{\circ}$ de maio de 1943, poderão autorizar, de forma irrevogável e irretratável, o desconto em folha de pagamento ou na sua remuneração disponível dos valores referentes ao pagamento de empréstimos, financiamentos, cartôes de crédito e operaçôes de arrendamento mercantil concedidos por instituiçóes financeiras e sociedades de arrendamento mercantil, quando previsto nos respectivos contratos.

$\$ 1$ o $\mathrm{O}$ desconto mencionado neste artigo também poderá incidir sobre verbas rescisórias devidas pelo empregador, se assim previsto no respectivo contrato de empréstimo, financiamento, cartáo de crédito ou arrendamento mercantil, até o limite de 35\% (trinta e cinco por cento), sendo 5\% (cinco por cento) destinados exclusivamente para:

I - a amortizaçáo de despesas contraídas por meio de cartáo de crédito; ou

II - a utilizaçáo com a finalidade de saque por meio do cartâo de crédito.

Deste modo, as parcelas de empréstimo consignado não podem ultrapassar 35\% dos ganhos líquidos do cliente. Porém, como $5 \%$ refere-se somente a gastos com cartão de crédito, o limite estabelecido e que deve ser respeitado é o de 30\% do salário auferido. Assim, os trabalhadores contam com previsão legal expressa de um teto a ser obedecido nos descontos de consignados em folha de pagamento, ainda que tenham autorizado o banco a proceder às mencionadas deduçóes.

Por fim, a relação travada in casu é inequivocamente de consumo, nos termos do artigo

\footnotetext{
1 SCHAEFER, S. V. D. Empréstimo consignado aos beneficiários do INSS e o uso do contrato de adesáo. Adlogados, 2018.

2 GONÇALVES, C. R. Direito Civil Brasileiro: contratos e atos unilaterais. 15a ed. São Paulo: Saraiva Educação, 2018.

3 BRASIL. Lei Federal no 10.820/2003. Dispóe sobre a autorização para desconto de prestaçóes em folha de pagamento, e dá outras providências. Diário Oficial da Uniấo. Poder Executivo, Brasília, DF, 18 dez. 2003.
} 
$3^{\circ}, \S 2^{\circ}$ da Lei no 8.078/90, do Código de Defesa do Consumidor (CDC) ${ }^{4}$ e da Súmula $297 / S T J,{ }^{5}$ razão pela qual são inteiramente aplicáveis as normas de ordem pública protetivas do consumidor.

\section{DIREITO DO CONSUMIDOR COMO DIREITO FUNDAMENTAL}

A defesa do consumidor como direito fundamental é um princípio basilar a ser integrado em quaisquer análises de pleitos de natureza consumerista. Esta noção é ainda mais relevante no contexto atual de abusos da relação jurídica por parte de fornecedores. Não é incomum que se observe empresas dispensando serviços inadequados sem maiores preocupaçóes com repercussóes negativas. Isto ocorre apoiado em uma assimilação geral de que o judiciário é moroso e caro demais para o consumidor médio em um país desigual como este, de maneira que muitos clientes deixam de buscar devidas compensaçóes na esfera judicial. Já para aqueles que chegam a ajuizar um processo, a lentidâo favorece às corporaçóes, que podem arcar com duradouras e custosas demandas. A aludida práxis deve ser combatida por atores políticos e institucionais, em prol da dignidade do consumidor como um autêntico direito da personalidade.

Conceitualmente, Tartuce \& Neves enquadram o direito do consumidor como um direito fundamental de terceira dimensão, pois se relaciona com a fraternidade na divisão clássica associada ao lema da Revolução Francesa. Essa noção traduz que o direito do consumidor "visa à pacificação social, na tentativa de equilibrar a díspar relação existente entre fornecedores e prestadores". ${ }^{6}$ A descrição dos doutrinadores ilustra porque a norma consumerista goza de guarida constitucional, haja vista seu alcance e aplicabilidade horizontal em quaisquer relaçóes de consumo.

Em função disso, conforme disposto no rol de direitos e garantias fundamentais do art. $5^{\circ}$, no inciso XXXII, a proteção do consumidor é um direito fundamental. ${ }^{7}$ Tal previsão alça o direito do consumidor a uma posição de destaque no ordenamento jurídico nacional. Sarlet ${ }^{8}$ define que os direitos fundamentais são a positivação dos valores mais básicos da sociedade, um núcleo substancial de direitos que precisa ser conservado. Destarte, as normas consumeristas estão incluídas nesse grupo, ganhando grande proeminência e

\footnotetext{
4 Art. $3^{\circ}$. Fornecedor é toda pessoa física ou jurídica, pública ou privada, nacional ou estrangeira, bem como os entes despersonalizados, que desenvolvem atividade de produção, montagem, criação, construção, transformação, importaçáo, exportação, distribuição ou comercialização de produtos ou prestaçáo de serviços. $\$ 2^{\circ}$ Serviço é qualquer atividade fornecida no mercado de consumo, mediante remuneração, inclusive as de natureza bancária, financeira, de crédito e securitária, salvo as decorrentes das relaçóes de caráter trabalhista.

5 Súm. 297/STJ: "O Código de Defesa do Consumidor é aplicável às instituiçôes financeiras".

6 TARTUCE, F. NEVES, D. A. A. Manual de direito do consumidor: direito material e processual. $7^{\mathrm{a}} \mathrm{ed}$. rev., atual. e ampl. São Paulo: Método, 2018, p. 26.

7 Art. 5, XXXII - o Estado promoverá, na forma da lei, a defesa do consumidor.

8 SARLET, I. W. A eficácia dos Direitos Fundamentais: uma teoria geral dos direitos fundamentais na perspectiva constitucional. 10a. ed. Porto Alegre: Livraria do Advogado, 2011.
} 
elevada carga axiológica, tendo preponderância sobre outras leis que tangenciam a matéria.

É pacífico na doutrina o entendimento do direito do consumidor como direito fundamental, especialmente pelo caráter principiológico que emana da sua posição na Constituição da República. Com efeito, Nunes ${ }^{9}$ define que:

o caráter principiológico específico do CDC é apenas e táo somente um momento de concretização dos princípios e garantias constitucionais, [...] [pois] o que a lei consumerista faz é tornar explícitos, para as relaçôes de consumo, os comandos constitucionais.

O caráter fundamental conferido pela Constituiçãoà defesa do consumidor, especificamente ao subsistema do $\mathrm{CDC}$ (cuja elaboraçáo foi prevista no art. $48, \mathrm{ADCT}^{10}$ ), significa que as normas atinentes à matéria dialogam frequentemente com a dignidade da pessoa humana, fundamento da República expresso no artigo $1^{\circ}$, III da Carta Magna. Este é o princípio basilar de todo o bloco constitucional brasileiro, e que também se manifesta no âmbito das relações consumeristas. $\mathrm{Na}$ "sociedade de consumo", a dignidade do consumidor é posta à prova constantemente, conforme enunciam Dahinten $\&$ Dahinten ${ }^{11}$ :

[...] Pelo menos considerando a realidade brasileira, é inegável tratar-se, a defesa do consumidor, seja na perspectiva formal, seja na material, de um direito fundamental. Da mesma forma, não faltam subsídios para enquadrar a defesa do consumidor, também, com um verdadeiro direito humano, sobretudo considerando as características da sociedade de consumo hoje reinante no mundo e a essencialidade do ato de consumir para o homem.

No Brasil, principalmente no âmbito dos Juizados Especiais Cíveis, observa-se um abarrotamento do Poder Judiciário nesta seara. Existem inúmeras açôes consumeristas, provenientes do atendimento ruim que é oferecido por diversos fornecedores, especialmente grandes conglomerados que massificam suas atividades em detrimento da qualidade do serviço prestado. Ademais, estas empresas possuem condiçóes de contratar as melhores assistências jurídicas disponíveis no mercado, ao passo que muitos consumidores lesados sequer buscam alguma prestação jurisdicional, de modo que compensa ao mau prestador de serviços a situação nestes moldes.

A relação desigualé um dos motivos para a ratificação constitucional da defesa do consumidor. Até a entrada em vigência do CDC, o que foi uma consequência direta da Constituição de 1988, as relaçôes consumeristas eram regulamentadas pelo Código Civil de 1916, o que náo supria a hipossuficiência dos consumidores frente às empresas. Logo, a desigualdade material inerente ao cenário fático se acentuava com julgamentos que consideravam o pacta

\footnotetext{
9 NUNES, R. Curso de direito do consumidor. 12a ed. São Paulo: Saraiva Educação, 2018, p. 78.

10 ADCT, Art. 48. O Congresso Nacional, dentro de cento e vinte dias da promulgaçáo da Constituiçáo, elaborará código de defesa do consumidor.

11 DAHINTEN, A. F.; DAHINTEN, B. F. A proteçáo do consumidor enquanto direito fundamental e direito humano: consolidação do mínimo existencial de consumo. Revista de Direito do Consumidor, São Paulo, v. 106, jan. 2017, p. 10.
} 
sunt servanda e a autonomia da vontade sem as devidas e necessárias relativizações. ${ }^{12}$

Assim, pode-se considerar que a finalidade precípua do Código de Defesa do Consumidor é fazer com que particulares, sejam estes pessoas físicas ou jurídicas, obedeçam ao direito fundamental da proteçáo ao consumidor. Outrossim, tal previsão consubstancia o princípio da dignidade da pessoa humana, que irremediavelmente passa pela dignidade do consumidor na sociedade contemporânea, eis que consumir é uma necessidade humana básica nos tempos atuais. ${ }^{13}$

E no que tange às necessidades básicas, os serviços bancários também podem ser assim classificados na esfera do consumo. A crise econômica pela qual passa o país hodiernamente é flagrante e assola principalmente aqueles menos favorecidos economicamente. Neste diapasão, a inevitabilidade de se tomar empréstimos junto às instituiçôes financeiras é uma realidade presente em diversos lares brasileiros. Essa premência pode ser utilizada por essas organizaçóes para empreender práticas exorbitantes, que se aproveitam da hipossuficiência de seus clientes para fornecer empréstimos sem maiores verificaçóes da capacidade financeira do consumidor, gerando superendividamento. Este fenômeno é assim definido por Marques ${ }^{14}$ :

O superendividamento pode ser definido como impossibilidade global do devedor-pessoa física, consumidor, leigo e de boa-fé, de pagar todas as suas dívidas atuais e futuras de consumo (excluídas as dívidas com Fisco, oriunda de delitos e de alimentos). Este estado é um fenômeno social e jurídico, a necessitar algum tipo de saída ou solução pelo Direito do Consumidor, a exemplo do que aconteceu com a falência e concordata no Direito da Empresa, seja o parcelamento, os prazos de graça, a redução dos montantes, dos juros, das taxas, e todas as demais soluçóes possíveis para que possa pagar ou adimplir todas ou quase todas as suas dívidas, frente a todos os credores, fortes e fracos, com garantias ou não. Estas soluçóes, que vão desde a informação e o controle da publicidade, direito de arrependimento, para prevenir o superendividamento, assim como para tratá-lo são fruto dos deveres de informaçấo, cuidado e principalmente de cooperação e lealdade oriundas da boa-fé para evitar a ruína do parceiro (exceção da ruina), que seria esta sua "morte civil", exclusão do mercado de consumo ou sua "falência" civil com o superendividamento.

É sobre este contexto que se debruça a presente pesquisa. Tal realidade deve ser combatida pelo Poder Judiciário e pelas funçóes essenciais à justiça, como a advocacia privada, a Defensoria Pública e o Ministério Público.

12 FILHO, E. C. L. A defesa do consumidor como um direito fundamental: aspectos relevantes da constitucionalização do direito. Revista Jus Navigandi, Teresina, ano 20, n. 4397, jul. 2015. Disponível em: https://jus.com.br/artigos/40894. Acesso em: 16 nov. 2019.

13 MIRAgEM, Bruno. Curso de Direito do Consumidor. 2. ed. São Paulo: Ed. RT, 2010.

14 MARQUES, Cláudia Lima. Sugestôes para uma lei sobre o tratamento do superendividamento de pessoas físicas em contratos de crédito ao consumo: proposiçôes com base em pesquisa empírica de 100 casos no Rio Grande do Sul. Revista de Direito do Consumidor, ano 14, n. 56, out.-dez. 2005, p. 12. 


\section{MANUTENÇÃO DA MARGEM CONSIGNÁVEL DE $30 \%$ COMO MATERIALIZAÇÁOO DA DIGNIDADE DO CONSUMIDOR}

Este estudo originou-se da representação judicial realizada pelo autor na sua prática advocatícia, quando ajuizou ação de obrigação de fazer em nome de seu cliente visando a redução da margem de descontos de empréstimos consignados ao percentual de $30 \%$ do seu salário líquido. No caso em tela, as parcelas descontadas eram provenientes de empréstimos contraídos em dois bancos diferentes, e somavam $51,4 \%$ do salário líquido do cliente. Tamanho desconto é inaceitável na medida em que se trata de verbas de caráter alimentar, o que afeta decisivamente a subsistência do cliente. À vista disso, não restou alternativa senão socorrer ao Judiciário para reduzir a margem consignada ao percentual de $30 \%$, o que foi reconhecido em decisão de primeira instância. ${ }^{15}$

Portanto, é flagrante a desproporcionalidade entre os descontos advindos de contratos de fornecimento de crédito, que já incluem encargos e juros acumulados em progressáo geométrica, e o valor integral dos vencimentos do requerente. Não se pode olvidar que as instituições financeiras, cuja finalidade principal é a obtenção de lucro, concedem sucessivos empréstimos, por vezes não se acautelando quanto à capacidade de pagamento do consumidor, colocando-o em desvantagem exagerada, ou seja, algo incompatível com a boa-fé objetiva e a igualdade material. O bem jurídico da dignidade do consumidor é um direito fundamental da personalidade a ser resguardado, e que se sobrepóe ao direito de satisfaçáo do crédito por parte dos bancos.

É consabido que nas últimas décadas, com esteio do Neoconstitucionalismo e do Direito Civil-Constitucional, o princípio constitucional da Dignidade da Pessoa Humana deve permear a análise dos termos do contrato assinado, quando assim for pertinente. ${ }^{16}$ Mesmo que o instrumento possua a anuência do consumidor, sabe-se que o princípio da autonomia privada não é absoluto e deve respeito aos princípios legais e constitucionais, como a função social do contrato, a boa-fé objetiva e a razoabilidade, sob o risco de ferir o sustento do contratante hipossuficiente. Por decorrência lógica, e em homenagem aos princípios acima elencados, há de ser procedida a redução da margem consignável em apreço ao patamar de

15 AÇÃO ORDINÁRIA No 0003131-05.2019.8.19.0004 (SÃO GONÇALO/RJ). DIREITO DO CONSUMIDOR. Por fim, quanto ao pedido de compensação dos danos morais, entendo presente violação aos direitos da personalidade. A quantia descontada é vultuosa e representa débito de caráter alimentar. Todavia, deve ser sopesado no quantum que a parte possui débitos junto ao banco. Em atenção aos arts. $5^{\circ}, \mathrm{X}$ da CR, 6o, VI e VII do CDC e ao viés punitivo-pedagógico do instituto, arbitro como sendo proporcional e razoável a quantia de $\mathrm{R} \$ 2.000,00$ (dois reais). Ante o exposto, julgo PROCEDENTE, na forma do art. 487, I do CPC, o pedido e condeno ambos os réus de forma solidária: 1) a limitar os descontos em conta corrente em 30\% (trinta por cento) dos ganhos líquidos da parte autora, excetuados os descontos legais, devendo se abster de realizar descontos a maior, no prazo de até 10 (dez) dias úteis, sob pena de multa equivalente ao dobro de cada desconto indevido, e, 2) ao pagamento da quantia de $\mathrm{R} \$ 2.000,00$ (dois mil reais) a título de compensação dos danos morais, com correção monetária do arbitramento e juros de mora de $1 \%$ ao mês da citação.

16 FILHO, E. C. L. A defesa do consumidor como um direito fundamental: aspectos relevantes da constitucionalização do direito. Revista Jus Navigandi, Teresina, ano 20, n. 4397, jul. 2015, passim. Disponível em: https://jus.com.br/artigos/40894. Acesso em: 16 nov. 2019. 
$30 \%$, de maneira a conformar os descontos na forma prevista em lei. ${ }^{17}$

Ainda que o demandante tenha celebrado os contratos com os bancos réus no afã de socorrer-se, é certo que as instituiçôes financeiras possuem a obrigação e a capacidade de verificar o potencial de endividamento de seus clientes antes de autorizar empréstimos, sobretudo com descontos automáticos em conta corrente ou na própria folha de pagamento. A legislação e a jurisprudência são uníssonas em proteger as garantias e princípios constitucionais dos mutuários, uma vez que as relaçôes de cunho financeiro têm como parte mais poderosa as grandes empresas bancárias que fornecem linhas de crédito para a população largamente endividada. Este é o entendimento do Superior Tribunal de Justiça. ${ }^{18}$

17 PÁDUA, F. R. C. de. Empréstimo consignado em folha de pagamento. Comentários ao artigo $2^{\circ}, \$ 2^{\circ}$, da Lei $n^{\circ}$ 10.820/03. Revista Jus Navigandi, Teresina, ano 14, n. 2316, 3 nov. 2009. Disponível em: https:// jus.com.br/artigos/13780. Acesso em: 15 nov. 2019.

18 AGRAVO DE INSTRUMENTO - $1^{\text {a }}$ Ementa Des(a). LUIZ FERNANDO DE ANDRADE PINTO - Julgamento: 22/03/2017 - VIGÉSIMA QUINTA CÂMARA CÍVEL CONSUMIDOR AGRAVO DE INSTRUMENTO. EMPRÉSTIMOS CONSIGNADOS. SERVIDOR PÚBLICO MUNICIPAL. DECISÃO IMPUGNANDA QUE INDEFERIU A LIMITAÇÃO DOS EM 30\% DOS RENDIMENTOS BRUTOS, SUBTRAÍDOS OS DESCONTOS COM IMPOSTO DE RENDA E PREVIDÊNCIA. SUPERENDIVIDAMENTO. RETENÇÃO DE VALORES EM CONTA-CORRENTE, ORIUNDA DE EMPRÉSTIMO BANCÁRIO OU DE UTILIZAÇÃO DE CARTÃO DE CRÉDITO, NÃO PODE ULTRAPASSAR O PERCENTUAL DE 30\% DO SALÁRIO DO CORRENTISTA. INTELIGÊNCIA DOS VERBETES SUMULARES No 200 E 295, DO TJRJ. PROVIMENTO DO RECURSO. 1. "A retenção de valores em conta corrente oriunda de empréstimo bancário ou de utilização de cartão de crédito não pode ultrapassar o percentual de $30 \%$ do salário do correntista." Súmula no 200, TJRJ); 2. "Na hipótese de superendividamento decorrente de empréstimos obtidos de instituiçóes financeiras diversas, a totalidade dos descontos incidentes em conta corrente náo poderá ser superior a $\mathbf{3 0} \%$ do salário do devedor." (Súmula no 295, TJRJ); 3. "Essa orientaçáo vem sendo seguida por ambas as Turmas componentes da Segunda Seção, entendendo-se, todavia, que os descontos contratados devem observar o limite de 30\% da remuneraçáo bruta, subtraídos o Imposto de Renda e os descontos previdenciários. "(AgRg no AREsp 66002 / RS- Min. Rel. Raul Araújo - Quarta Turma- Julgado em: 21/08/2014); 4. Nesse sentido, é possível ao servidor comprometer contratualmente até $30 \%$ de sua remuneração mensal desde que nesse percentual estejam subtraídos necessariamente os descontos obrigatórios. Jurisprudência do Col. STJ e desta Eg. Corte; 5. Recurso provido, nos termos do voto do Relator. Íntegra do Acórdáo - Data de Julgamento: 22/03/2017

ADMINISTRATIVO. SERVIDOR PÚBLICO. DESCONTOS EM FOLHA DE PAGAMENTO. LIMITE DE 30\% (TRINTA POR CENTO) DOS VENCIMENTOS. AGRAVO REGIMENTAL DESPROVIDO.

Os descontos na folha de pagamento de servidor público devem ser limitados a 30\% (trinta por cento) de sua remuneraçáo, em funçáo do princípio da razoabilidade e do caráter alimentar dos vencimentos. Precedentes. 2. Agravo Regimental do BANCO SANTANDER desprovido. (STJ; AgRg no REsp 979.442/ MS, Rel. Ministro NAPOLEÃO NUNES MAIA FILHO, PRIMEIRA TURMA, julgado em 09/06/2015, DJe 19/06/2015).

ADMINISTRATIVO. CONSUMIDOR. Trata-se de recurso especial (...), fundamentado no artigo 105, inciso III, alíneas a e c, da Constituição Federal, manejado em face de acórdão proferido pelo Tribunal de Justiça do Estado do Paraná. Nas razóes do especial, alega a parte recorrente, violação dos artigos 187 e 944 do CC, 535 e 649, IV, do CPC, 6º IV e V, 14, 51, I e IV, do CDC e à Súmula 297/STJ e dissídio jurisprudencial.(...) Com efeito, no que pertine ao desconto em folha, a decisão proferida pelo Tribunal a quo, ao limitar em $30 \%$ (trinta por cento) os descontos decorrentes de empréstimo bancário efetuados na conta-corrente do ora recorrente, está em consonância com o posicionamento firmado por este Egrégio Tribunal, no sentido de não se admitir que a instituição financeira se aproprie integralmente do salário do cliente depositado em sua conta corrente, com o objetivo de solver a divida decorrente do contrato de empréstimo, ainda 
No escólio jurisprudencial dos tribunais superiores, tem sido observada a garantia legal sobre empréstimos bancários. Estes não podem tomar dos trabalhadores parte tão grande de seus salários a ponto de deixá-los sem o amparo de tudo o que é constitucionalmente garantido como direitos fundamentais básicos. Consoante o supracitado, o princípio constitucional da dignidade da pessoa humana prevalece sobre os termos do contrato assinado. Dessa maneira, compete aos bancos e fornecedoras de crédito o cumprimento do percentual legalmente prescrito, sob pena de serem judicialmente impelidos a moldarem os empréstimos nos termos das normas em vigor.

Insta salientar que esta cogniçáo já deve ser aplicada em sede de tutela de urgência. Não se pode subestimar o fato de que a controvérsia aqui abordada versa essencialmente sobre verbas alimentares, de sorte que a prestação jurisdicional deve ser ágil com o intuito de reestabelecer a justiça, ainda que provisoriamente. Já no que concerne aos critérios disciplinados no art. 300 do $\mathrm{CPC} / 2015$, a probabilidade do direito é flagrante por mera leitura do art. $1^{\circ}, \$ 1^{\circ}$ da Lei Federal no $10.820 / 2003$. Também não há risco ao resultado útil do processo, tampouco dano irreparável. De fato, não é razoável suscitar a noção de dano irreparável aos réus em questão. Foi este o julgamento obtido em recente decisão interlocutória transcrita. ${ }^{19}$

que exista previsáo contratual para tanto. Isso porque, tais verbas, por terem nítido caráter alimentar, não podem sofrer qualquer tipo de constrição" (STJ, Resp 1.227.376-PR (2010/0218179-1), 3a-T., j. Em 7.2.2011, Rel. O Min. VASCO DELLA GIUSTINA).

19 PROCESSO No 0099705-85.2019.8.19.0038 (NOVA IGUAÇU/RJ). 1- Defiro JG. 2- Trata-se de açáo de OBRIGAÇÃO DE FAZER COM PEDIDO DE TUTELA DE URGÊNCIA [...], na qual a parte autora visa em tutela de urgência diminuição dos valores das prestações de empréstimos ao limite de $30 \%$ do salário líquido. Muito embora o deferimento da tutela antecipada não dependa de profunda dilação probatória, devem estar presentes os requisitos constantes no art. 300 do CPC, quais sejam, a prova inequívoca capaz de convencer da verossimilhança da alegação e o fundado receio de dano irreparável ou de difícil reparação. À luz desses elementos, conclui-se que, para se obter a antecipação de tutela, é necessário que os elementos probatórios evidenciem a veracidade do direito alegado, formando um juízo máximo e seguro de probabilidade. Após análise da narrativa da inicial, verifico a existência de prova inequívoca quanto à verossimilhança das alegaçóes da parte autora, uma vez que a retençáo superior a 30\% dos rendimentos líquidos do autor para pagamento de débitos, compromete sua a subsistência e afronta ao princípio basilar da dignidade humana. O direito à satisfação do crédito, não obstante seja assegurado na Constituição da República, não é absoluto, devendo ser relativizado quando em conflito com a garantia fundamental do mínimo existencial à sobrevivência digna. Assim, não sendo caso de irreversibilidade da medida, imperiosa concessão da tutela de urgência em sua integralidade, de modo que os descontos fiquem adstritos a (30) trinta por cento dos ganhos líquidos do autor não sobre sua remuneração bruta. Neste sentido, temos a Súmula 295 do TJRJ : 'Na hipótese de superendividamento decorrente de empréstimos obtidos de instituiçóes financeiras diversas, a totalidade dos descontos incidentes em conta corrente não poderá ser superior a 30\% do salário do devedor.' Neste diapasão, é a jurisprudência recente deste Tribunal de Justiça: DESCONTOS AO PERCENTUAL DE 30 \% DOS VENCIMENTOS. A retenção de valores em conta corrente oriunda de empréstimos bancários não pode ultrapassar o percentual de 30\% dos rendimentos do correntista. Inteligência do verbete sumular n. ${ }^{\circ} 200$ do E. TJRJ. Sentença que fixou o limite os descontos das parcelas de todos os contratos realizados no percentual de 30\% (trinta por cento) dos rendimentos brutos da autora, diante do superendividamento da apelada. Sentença que merece um reparo de ofício haja vista que o pedido da autora se restringe aos rendimentos líquidos, e não rendimentos brutos. Teses recursais que merecem rejeição, já que a negociação em tela sujeitase à limitação de descontos máximos de 30\% dos rendimentos líquidos do mutuário. RECURSO A QUE SE CONHECE E AO QUAL SE NEGA SEGUIMENTO. (DES. NATACHA TOSTES OLIVEIRA Julgamento: 08/06/2015 - VIGESIMA SEXTA CAMARA CIVEL CONSUMIDOR). Ante ao exposto, DEFIRO O PEDIDO TUTELA DE URGÊNCIA para determinar que os réus limitem os descontos na folha de pagamento do autor, de modo que fiquem adstritos a 30\% do vencimento líquido da autor, sob 
Notoriamente existe um grupo de bancos que detêm um seleto oligopólio da atividade bancária neste país. É fato público e amplamente divulgado que estas poucas instituições financeiras vêm apresentando lucros bilionários, passando ao largo da grave crise que aflige o Brasil na última década. Via de consequência, é uma violação ao princípio constitucional da razoabilidade que se ventile a ocorrência de dano irreparável aos grandes bancos que atuam neste país, por serem compulsoriamente constrangidos a reduzir os descontos a título de empréstimos consignados, com a finalidade de se adequar à legislação vigente e ao espírito da Constituição Cidadã.

Assim, deve ser rechaçada de plano a conduta das instituições financeiras de se apropriarem de considerável parte da remuneração de seus clientes para reembolsarem os empréstimos concedidos, sem antes realizarem um prévio e rigoroso controle sobre a saúde financeira do eventual mutuário. $\mathrm{O}$ consumidor, parte hipossuficiente nesta associação, tem de ser preservado de descontos que comprometam a proteção constitucionalmente assegurada ao seu salário (artigo $7^{\circ}, \mathrm{X}, \mathrm{CRFB}$ ), bem como sua própria sobrevivência, em consonância com o princípio da dignidade da pessoa humana.

\section{CONSIDERAÇÓES FINAIS}

$\mathrm{Na}$ contemporânea sociedade de consumo, é flagrante a utilização de condutas questionáveis por parte de fornecedores, que se apoiam na hipossuficiência do consumidor para oferecerem serviços falhos e não serem propriamente responsabilizados por isso. Instituiçóes bancárias se inserem neste enquadramento, haja vista o reconhecimento da natureza consumerista do serviço prestado e o grande poderio econômico e político que têm à disposição. Nos últimos anos, de forma inversamente proporcional às adversidades vivenciadas pela maior parte da população brasileira, essas organizaçóes têm experimentado crescimento exponencial e sucessivos lucros bilionários, o que está intrinsecamente associado ao panorama socioeconômico atual.

Devido à implacável crise que acossa o Brasil, cada vez mais as pessoas estão recorrendo a empréstimos bancários, dentre os quais a consignação em contracheque oferece menos restriçōes para que seja obtida. A exemplo do foi demonstrado neste artigo, esta é uma modalidade vantajosa para as financeiras, uma vez que a possibilidade de inadimplência é consideravelmente menor com descontos efetuados diretamente no salário do cliente. Em se tratando de somente um banco ou instituição financeira, não há maiores dúvidas quanto à retificação para recuo da margem consignável até o limite legal de 30\%. Contudo, ainda não há jurisprudência suficientemente pacífica para demarcar uma posição segura aos consumidores quando se trata de dois ou mais empréstimos contraídos em empresas diversas.

A despeito disso, o direito consumerista possui o condão de mitigar a hipossuficiência

pena pena de multa equivalente ao dobro de cada parcela descontada. Oficie-se à fonte pagadora do teor desta decisão. Citem-se. Intimem-se. 
do consumidor nas desequilibradas relaçóes com grandes fornecedores. Isso deve ser reproduzido nos casos em que práticas predatórias são identificadas, como a concessão de empréstimos sem acurado exame das condiçóes do cliente de arcar com as parcelas descontadas diretamente em contracheque. No espírito da Constituição de 1988, essa é uma obrigaçáo das empresas fornecedoras de crédito, uma vez que o superendividamento acarreta em grave declínio da qualidade de vida e integridade psíquica do cidadáo, interferindo na sua dignidade enquanto direito da personalidade.

Decerto que a consagraçáo da defesa do consumidor como direito fundamental na Constituição Cidadã de 1988 foi uma indispensável evoluçáo legislativa, pois essa previsão ocorre pela materialização que o direito do consumidor confere ao princípio fundamental da dignidade da pessoa humana. Todos os sujeitos inevitavelmente serão consumidores em dado momento, o que representa uma verdade inexorável: a salvaguarda da dignidade do consumidor é fundamental para que o valor central do ordenamento jurídico brasileiro seja obedecido na realidade fática.

\section{REFERÊNCIAS}

BRASIL. Constituição da República Federativa do Brasil. Vade Mecum 2019. São Paulo: Saraiva, 2019.

Lei Federal no 10.820/2003. Dispóe sobre a autorizaçáo para desconto de prestaçóes em folha de pagamento, e dá outras providências. Diário Oficial da Uniáo. Poder Executivo, Brasília, DF, 18 dez. 2003. Disponível em: http://www.planalto.gov.br/ ccivil_03/leis/18078.htm. Acesso em: 15 nov. 2019.

Lei no 8.078/1990. Código de Defesa do Consumidor. Diário Oficial da Uniáo. Poder Executivo, Brasília, DF, 12 set. 1990. Disponível em: http://www.planalto. gov.br/ccivil_03/LEIS/2003/L10.820.htm. Acesso em: 15 nov. 2019.

DAHINTEN, A. F; DAHINTEN, B. F. A proteção do consumidor enquanto direito fundamental e direito humano: consolidação do mínimo existencial de consumo. Revista de Direito do Consumidor, São Paulo, v. 106, jan. 2017. Disponível em: http://www. mpsp.mp.br/portal/page/portal/documentacao_e_divulgacao/doc_biblioteca/bibli_servicos_ produtos/bibli_boletim/bibli_bol_2006/RDCons_n.106.05.PDF. Acesso em: 15 nov. 2019.

FILHO, E. C. L. A defesa do consumidor como um direito fundamental: aspectos relevantes da constitucionalização do direito. Revista Jus Navigandi, Teresina, ano 20, n. 4397, jul. 2015. Disponível em: https://jus.com.br/artigos/40894. Acesso em: 15 nov. 2019.

GONÇALVES, C. R. Direito Civil Brasileiro: contratos e atos unilaterais. 15a ed. São Paulo: Saraiva Educação, 2018. 
MARQUES, C. L. Sugestôes para uma lei sobre o tratamento do superendividamento de pessoas físicas em contratos de crédito ao consumo: proposiçôes com base em pesquisa empírica de 100 casos no Rio Grande do Sul. Revista de Direito do Consumidor, São Paulo, ano 14, n. 56, out.-dez. 2005.

MIRAGEM, Bruno. Curso de Direito do Consumidor. 2. ed. São Paulo: Ed. RT, 2010.

NUNES, R. Curso de direito do consumidor. 12a ed. São Paulo: Saraiva Educação, 2018.

PÁDUA, F. R. C. de. Empréstimo consignado em folha de pagamento. Comentários ao artigo $2^{\circ}, \$ 2^{\circ}$, da Lei $n^{\circ} 10.820 / 03$. Revista Jus Navigandi, Teresina, ano 14, n. 2316, nov. 2009. Disponível em: https://jus.com.br/artigos/13780. Acesso em: 15 nov. 2019.

SARLET, I. W. A eficácia dos Direitos Fundamentais: uma teoria geral dos direitos fundamentais na perspectiva constitucional. $10^{\mathrm{a}}$. ed. Porto Alegre: Livraria do Advogado, 2011.

SCHAEFER, S. V. D. Empréstimo consignado aos beneficiários do INSS e o uso do contrato de adesáo. Adlogados, 2018. Disponível em: https://www.adlogados. $\mathrm{com} /$ artigos/visualizar/emprestimo-consignado-aos-beneficiarios-do-inss-e-o-uso-docontrato-de-adesao. Acesso em: 15 nov. 2019.

TARTUCE, F. NEVES, D. A. A. Manual de direito do consumidor: direito material e processual. $7^{\text {a }}$ ed. rev., atual. e ampl. São Paulo: Método, 2018. 